\title{
The Challenges of Inclusive Growth in Sub-Saharan Africa: A Comparative Analysis of Angola and Nigeria
}

\author{
S. Igbatayo*, B. Afolabi, Phd ${ }^{* *}$, And O. Babalola** \\ Department Of Economics \& Management Studies Afe Babalola University, Ado-Ekiti, Nigeria. \\ "Professor and Head of Department \\ *** Programme coordinator \\ Lecturer \\ Corresponding Author: * S. Igbatayo
}

\begin{abstract}
Since the turn of the Century, African economies have undergone considerable transformation, with consistent and robust growth, in sharp contrast to decades of slow or even negative growth, which characterized the 1970s into the 1990s. While the region's economies slowed down from an average of $5.6 \%$ during the period 2002-2008 to $2.2 \%$ in 2009, in the wake of the global financial crisis; Africa promptly recovered, with an average growth rate of $4.6 \%$ in 2010 and $6.2 \%$ in 2012, as well as 4.0 and $4.3 \%$ for 2013 and 2014, respectively. In Sub-Saharan Africa, economic growth is even more robust, averaging about $6 \%$ over the past decade. This development has made the region to be acknowledged with the second highest economic growth in the world in recent times. However, contemporary economic growth in Sub-Saharan Africa is largely unaccompanied by employment generation or increased livelihood opportunities. Consequently, poverty levels across the region remain relatively high, at $48 \%$ of the population. The challenges posed by lack of inclusive growth are particularly evident in Angola and Nigeria, countries that feature economies driven by the petroleum industry. Therefore, the major objective of this paper is to shed light on the challenges associated with lack of inclusive growth in Sub-Saharan Africa. The paper employs empirical data to analyze Angola and Nigeria case studies, which reveal both countries as resource-rich economies featuring relatively high economic profiles, devoid of widespread employment opportunities, with grave consequences for endemic poverty. Consequently, the paper presents a policy framework, grounded in poverty reduction strategies, enterprise development and capacity building aimed at promoting broad-based economic growth as the cornerstone of African economies.
\end{abstract}

Date of Submission: 14 -07-2017

Date of acceptance: $15-07-2017$

\section{Introduction}

1.0 Conceptualizing Inclusive Growth: A Multi-dimensional Perspective

The attack against global poverty late in the $20^{\text {th }}$ century into the new millennium has provoked a paradigm shift in development thinking, from structural adjustment to poverty reduction (UNDP, 2000.3; World Bank, 2000.6). There is a consensus amongst policy makers and researchers that economic growth alone is not sufficient to effect livelihood transformation, particularly in the developing world. What is even more important, in the view of many development experts, is the pattern and pace of economic growth; hence, the concept of inclusive growth, which has traditionally focused more on productive employment, particularly by the poor, than on the redistribution of income. The concept also attempts to merge poverty and growth analyses, while also making the analysis country-specific. Inclusive growth refers to both the pace and pattern of growth, which are considered interlinked and therefore needed to be addressed together (World Bank, 2009.2).

The term 'inclusive growth' is traceable to the turn of the century, when Kakwani and Pernia (2000.1) associated the concept with pro-poor growth. However, inclusive growth has emerged in literature as a concept distinct from pro-poor growth, with the notion of participating in and benefiting from growth processes associated with the broader concept of inclusive growth (Ramos et al, 2013.2).

Ianchovichina and Lundstrom (2009.2) in a study of inclusive growth, reveal that the concept of growth country analytics has a distinct focus on the pace and pattern of growth. Indeed, rapid growth is an imperative for substantial poverty reduction. However, growth should also be sustainable in the long-run and structured across economic sectors, and include a large proportion of the country's labour force. There is a consensus in the development community that the main instrument for inclusive growth is productive employment. Boosting employment generates new jobs and income for both poor and non-poor from wages earned in all types of firms, or from self-employment. Therefore, the ability of individuals to be productively employed depends on available opportunities to make full use of resources as the national economy evolves over time. Consequently, inclusive growth analytics embraces articulation of policies that should be implemented not only in the short- 
run, but also in the long-run. Figure 1 illustrates inclusive growth analytics. It shows how increases through productive employment fuel both economic growth and poverty reduction. It also illustrates the pivotal role played by both waged employment and self-employment in the transformation of livelihoods, critical to inclusive growth.

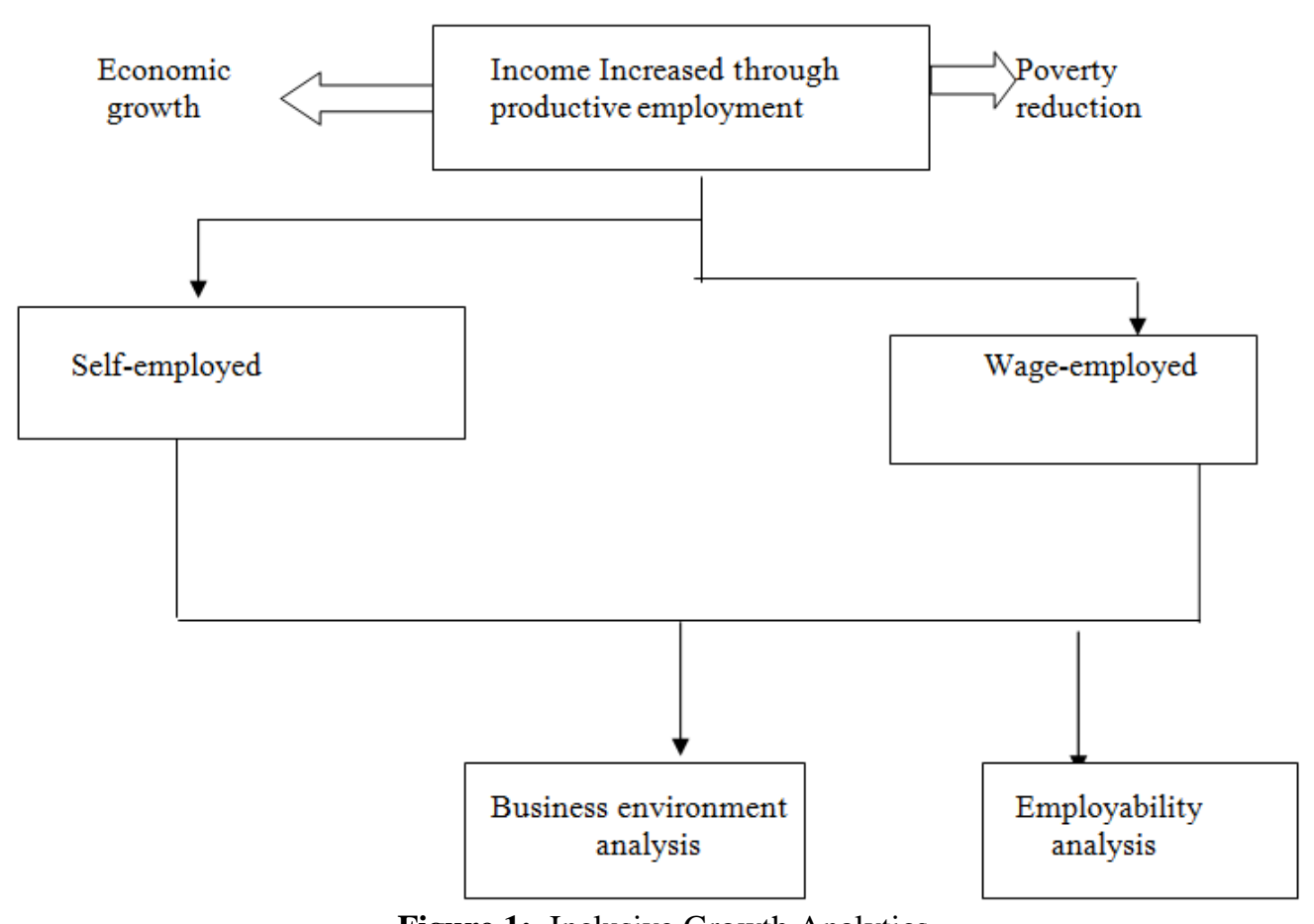

Source: Ianchovichina and Lundstrom (2009.8)

Policies that promote inclusive growth are now an important element of most government strategies. In the developing world, there are several countries which have recorded considerable economic growth over the last decade but without substantial reduction in poverty. This trend calls for inclusiveness of growth strategy in such nations. This is particularly true for African countries which have recorded relatively high economic growth in the past couple of decades but have been unable to reduce poverty significantly. The AfDB (2012.2), in a study on inclusive growth across Africa, emphasized that the concept is broad-based, cutting across all sectors and protecting the disadvantaged and marginalized groups from macro-economic shocks. According to the study, fostering inclusive growth requires consideration of diverse segments of society to include age, gender, regional or geographical gaps and balances, as well as sectoral differences. Therefore, long-term and sustainable economic growth that is high enough for poverty reduction must be accompanied by growing productive employment to combat inequality and foster inclusive growth, according to the AfDB report.

\subsection{The Challenges of Inclusive Growth in Sub-Saharan Africa}

Until recently, Sub-Saharan Africa had struggled with economic performance, characterized by slow or even negative growth throughout the 1980s into the 1990s. However, for the first time in a generation, there are reasons for optimism. An increasing number of countries in the region are recording economic progress, in a manifestation of better economic policies, grounded in structural reforms. Countries across the region have also successfully reduced domestic and external imbalances, resulting in economic efficiency. They have equally attracted a sustained flow of Foreign Direct Investment (FDI), which has been translated into more robust spending on healthcare, education, and other basic social services. In addition, governments across the region have embraced improved governance, reinforced by transparency, accountability and participatory framework (Basu et al, 2000.1).

However, Sub-Saharan Africa still faces numerous challenges that undermine its quest for economic transformation. Many economies in the region remain fragile and vulnerable to both domestic and external shocks. Despite the recent upturn in economic growth rates, poverty remains endemic and poses a threat to the realization of inclusive growth. Policy makers in the region continue to struggle with economic diversification and the need to integrate themselves into the global economy. Indications are that Africa's economies began a gradual turnaround in 1995, after decades of negative economic performance (Sala-i-matin \& Pinkovskiy, 2010.10). The pace of economic growth on the continent accelerated at the turn of the new Millennium as the 
trend widened amongst African economies. Economic growth on the continent averaged $6.5 \%$ between 2002 and 2007 (Arieff et al, 2010.5). Economic growth around the continent was driven by the global commodity boom; however, many other factors contributed as well. Both oil exporters and importers experienced growth beyond 5\% between 2004 and 2008, while investment extended beyond traditional foreign interests in extractive industries. Figure 2 shows regional trends in economic growth around the world between 2000 and 2010 , in comparison to Sub-Saharan Africa.

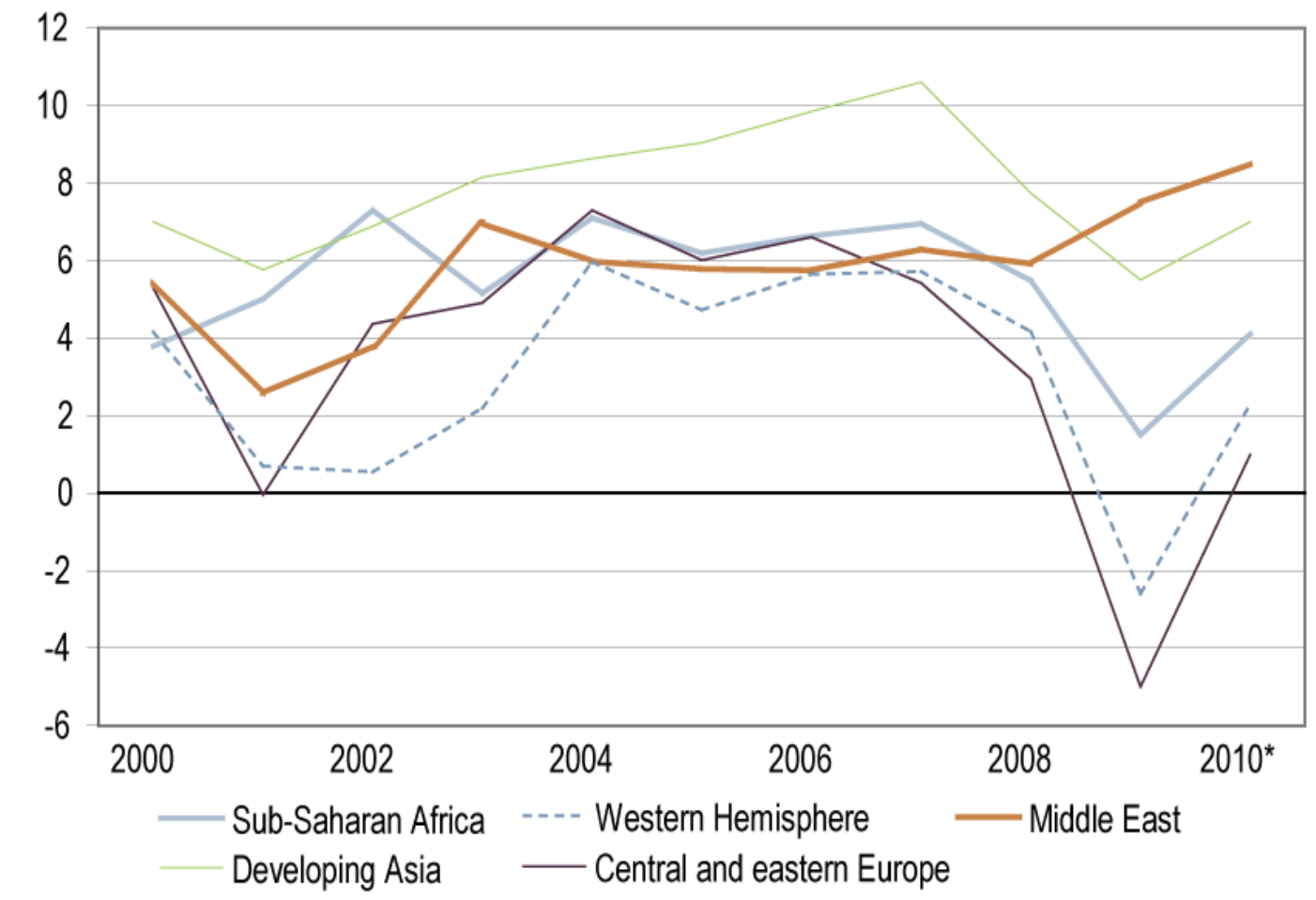

Figure 2: Regional Growth around the World, 2000-2010.

\section{Source: IMF, World Economic Outlook, 2011.25}

It shows the relatively high performance in GDP growth in Sub-Saharan Africa in comparison to other major regions of the world over the period in view. Rising economic fortunes in Sub-Saharan Africa, however, was constrained by the global economic crisis, which emerged with the meltdown of the United States' subprime mortgage market in 2007. The severe economic recession unleashed on the global economy is acknowledged as the most profound in over seventy years. Among other things, the global economic crisis was accompanied by a decline in international trade and finance, as well as a spread in financial contagion, which threatened global banking and financial markets. The crisis also unleashed macro-economic shocks on several economies in Sub-Saharan Africa, including rising inflation, unemployment and budget deficits, as well as a spike on food prices, which threatened social instability across the region.

However, as Figure 2 illustrates, economic growth in Sub-Saharan Africa recovered rapidly from the global economic crisis, in a demonstration of resilience, while other major regions, except East Asia and the Pacific, continue to struggle against the crisis. In fact, six of the ten fastest growing economies in the world are in sub-Saharan Africa (The Economist, 2010.42). In the aftermath of the global economic crisis, several economies in the region gathered momentum and resumed economic growth as illustrated in Figure 3 . For example, the economies of Ethiopia and Uganda grew rapidly through the crisis. Indeed economic growth rebounded sharply in Uganda in 2010, up 4.7\% from $1.7 \%$ in 2009 just shy, of its 5\% pre-crisis level (20002008) average growth (World Bank, 2011.10). 


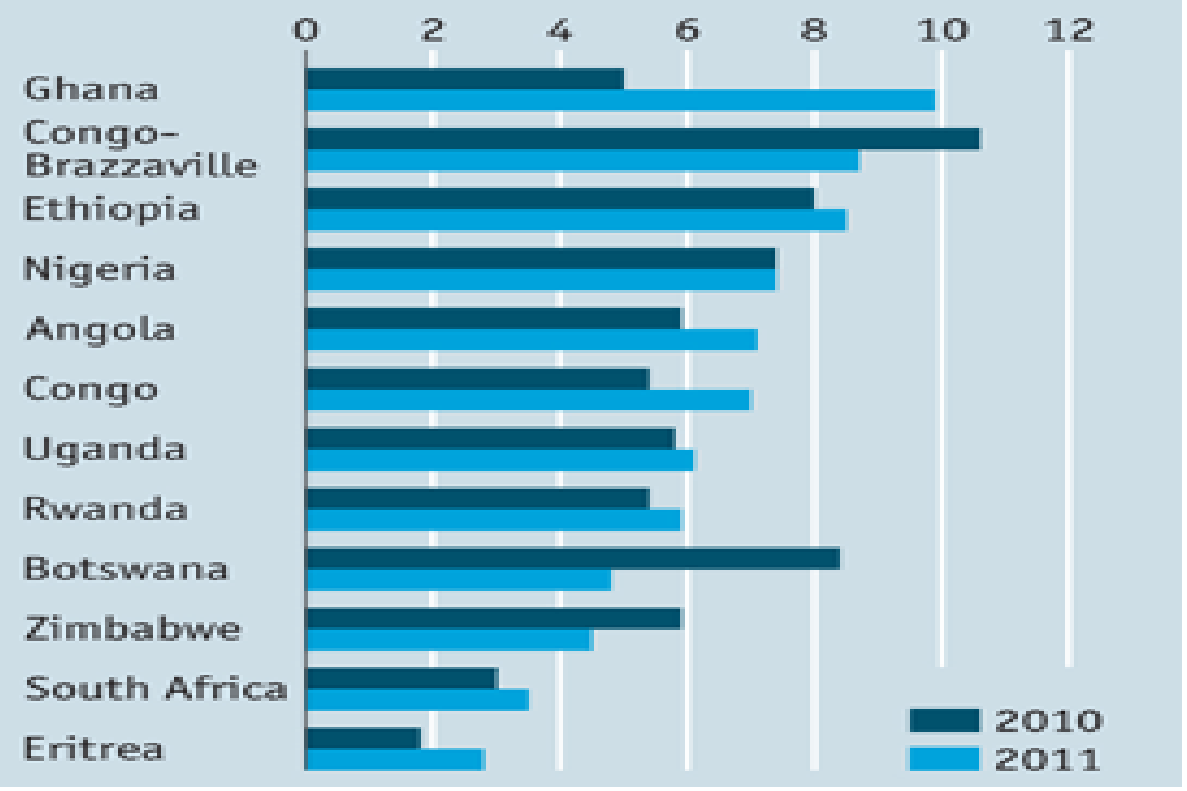

Figure 3: GDP Growth in Selected Economies in Sub-Saharan Africa, 2010-2011

\section{Source: IMF Database}

Economic growth in Sub-Saharan Africa has resumed its pre-crisis trajectory, as the global economy recovers from the recent economic recession. Economic growth in the region is driven by surging demand for Africa's primary commodities, as well as increasing domestic demand, underpinned by a surge in Foreign Direct Investment (FDI). Growth in the region strengthened to 4.5\% in 2014, after rising 3.7\% in 2012, $4.2 \%$ in 2013 and 4.5 in 2014. An interesting feature of the latest data on the region's growth profile shows that economic growth was relatively broad-based, with more than a third of countries around the region recording growth of $5 \%$ or more. Indeed, excluding South Africa, the region's second largest economy, average GDP growth for the rest of the region in 2013 was 6.0\%, second only to developing East Asia and the Pacific, at 7.2\% (World Bank, 2014.12). Capital flows to the region in 2013 was robust, at 5.8\% of regional GDP, but less than the $6.4 \%$ of regional GDP in 2012 due to a reduction in portfolio debt inflow to South Africa. After declining by $8.6 \%$ in 2012 , net foreign direct investment inflows to the region grew by $10.7 \%$ to US $\$ 31.9$ billion in 2013 , reinforced by new hydrocarbon discoveries in several countries, including Mozambique and Tanzania (World Bank, 2014.13).

Economic growth in sub-Saharan Africa in 2013 featured a broad dimension. Growth was strong in resource-rich countries, including Sierra Leone and the Democratic Republic of Congo, attributable to high production in the mining sector. Also, growth rebounded in the post conflict countries of Cote D'Ivoire and Mali, underscored by improvement in political stability and the security situation.

Non-resource-rich countries, particularly Ethiopia and Tanzania experienced robust economic growth in 2013 as well (World Bank, 2013.5a). However, strong economic growth rates recorded by several economies in sub-Saharan Africa masked substantial variations in sub-regional trends. A disaggregation of data on economic growth across the region reveals interesting trends and developments. Table 1 shows real GDP growth rates across sub-regions in sub-Saharan Africa, from 2005 (including projections) to 2015.

Table 1: Sub-regional GDP growth in Sub-Saharan Africa, including Projections, 2005 - 2015

\begin{tabular}{|l|l|l|l|l|l|l|l|}
\hline Real GDP growth \% & $2005-09$ & 2010 & 2011 & 2012 & $2013(\mathrm{e})$ & $2014(\mathrm{p})$ & $2015(\mathrm{p})$ \\
\hline Central Africa & 4.1 & 5.9 & 4.4 & 5.8 & 3.7 & 6.2 & 5.7 \\
\hline East Africa & 7.1 & 7.3 & 6.3 & 3.9 & 6.2 & 6.0 & 6.2 \\
\hline Southern Africa & 5.2 & 3.7 & 3.9 & 3.3 & 3.0 & 4.0 & 4.4 \\
\hline West Africa & 5.7 & 7.1 & 6.9 & 6.9 & 6.7 & 7.2 & 7.1 \\
\hline Sub-Saharan Africa (SSA) & 5.6 & 5.6 & 5.5 & 4.9 & 5.0 & 5.8 & 5.9 \\
\hline
\end{tabular}

Source: Adapted from Africa Economic Outlook, 2014.31.

Data in Table 1 show that East and West Africa recorded the fastest growth rates in Sub-Saharan Africa, above 6\%. Overall, growth in sub-Saharan Africa in 2013 was 5\% and projected to be $5.8 \%$ and $5.9 \%$ for 2014 and 2015, respectively. 
Despite the robust growth rates recorded across Sub-Saharan Africa since the turn of the Millennium, the positive development is largely unaccompanied by employment generation. In a reflection of structural difficulties which the region's economies face, there is indeed lack of inclusive growth across the region. Also, according to the result of a survey conducted across 34 African countries, there was little change in the level of poverty at the grassroots level after a decade of economic growth (Sy, 2014.2). Also, a recent report by the International Labour Organization (ILO, 2014.10) reveals that Sub-Saharan African has the highest rate of vulnerable employment in the world, estimated at $77.4 \%$ in 2013 . Vulnerable employment is defined as unpaid family workers and own-account workers as a percentage of the labour force. The ILO report also reveals the proportion of working-age population in paid employment across Sub-Saharan Africa is low, at 13.7\%. This is yet another affirmation to the lack of inclusive growth in the region.

Unemployment is also a major macro-economic challenge in the region. In a recent report, the United Nations Economic Commission for Africa (UNECA, 2013.10) reveals that unemployment rates have risen from 7.4\% to $8.2 \%$ between 1998 and 2009 in sub-Saharan Africa. Unemployment record is even more sobering amongst the region's youths. While young people make up $40 \%$ of Africa's working-age population, they have the highest unemployment rates at $12 \%$ of the population in sub-Saharan Africa, according to the UNECA report. Overall, the report concludes that Africa's commodity-driven growth trends had done little to lower unemployment and poverty rates.

\section{An Overview Of Angola's Economic Profile \\ 2.1 Assessing Angola's Economic Performance: Recent Trends and Developments}

Following the resolution of the civil war in Angola, after 27 years of conflict, the economy gathered momentum for sustained growth. Indeed, between 2002 and 2008, Angola experienced some of its highest real GDP growth in its history (Angola Brief, 2012.1). After the nation's conflict ended in 2002, Angola's s real GDP grew 15\% per year between 2003 and 2007; rising from 3.3\% in 2003 to more than 20\% in 2007 and ranking the country amongst the world's top five performers (USAID, 2008.5). The high growth is driven by the global oil boom, soaring commodity prices, as well as government's reconstruction and rehabilitation programmes. By 2006, GDP growth outside the oil sector was estimated at $27.5 \%$, including strong performance in manufacturing and agriculture. However, oil and diamonds together accounted for about $61 \%$ of GDP.

The surging growth trend was constrained by the global economic crisis, which hit the global economy in 2008. Consequently, Angola's GDP contracted in 2009, undermined by the global plunge in crude oil prices. Petroleum and related activities contributed about 85\% to Angola's GDP in 2009; therefore, the decline in oil prices from US\$145.00/barrel to US\$30.28 was a major blow to government revenue and its budgetary obligation (WRI, 2011.2).

However, Angola's economy showed resilience against the onslaught of the global economic crisis. After a brief stagnation from 2009 to mid-2011, the economy resumed its growth trajectory, rising to $8.1 \%$ in 2012, from $3.1 \%$ in 2011. The oil sector remains the driving force propelling Angola's economy, as oil accounted for about $96 \%$ of its exports in 2012. In fact, growth in the oil sector rebounded from 5.6\% decline in 2011 to an estimated growth of 5.2\% in 2012, contributing 1.8\% to overall GDP growth (World Bank, 2013.2). During the year, the oil and gas sector contributed about $85 \%$ to GDP and about $80 \%$ of government revenue (KPMG, 2013.7). Diamond exports contributed an additional 5\% to the nation's export in 2012.

Angola, Africa's second largest producer of crude oil, grew by $6.8 \%$ in 2013 and $4.5 \%$ in 2014 . As usual, the nation's GDP was driven by oil activity, but non-oil sectors accounted for a significant proportion of the nation's GDP during the year, including agriculture, manufacturing and construction sectors. Table 2 shows Angola's major macro-economic indicators from 2013 to 2016.

Table 2: Angola- Selected Macroeconomic Indicators, 2012-2015

\begin{tabular}{|l|l|l|l|l|}
\hline & 2013 & $2014(\mathrm{e})$ & $2015(\mathrm{p})$ & $2016(\mathrm{p})$ \\
\hline Real GDP & 6.8 & 4.5 & 3.8 & 4.2 \\
\hline Real GDP/capita Growth & 3.7 & 1.4 & 0.7 & 1.1 \\
\hline CPI Inflation & 8.8 & 7.4 & 8 & 8.7 \\
\hline Budget balance \% GDP & 0.3 & -2.2 & -10.6 & -7.7 \\
\hline Current Account Balance\% GDP & 5.8 & 2.7 & -5.9 & -2.2 \\
\hline
\end{tabular}

Note: Estimates (e) and Projections (p)

Source: Africa Economic Outlook, 2015.3

Table 2 also shows projections for GDP growth for 2015 and 2016, placed at 3.8 and 4.2, respectively. 


\subsection{The Pivotal Role of Angola's Oil and Gas Sector to Contemporary Economic Growth}

Angola is sub-Saharan Africa's second largest crude oil producer, behind Nigeria. The nation's oil derivates industry accounts for $91.92 \%$ of total exports. Angola is a key player in Africa's oil industry as both a major producer and exporter. The nation's offshore activity is recognized as world-class, for both oil exploration and production (KPMG, 2013.21). Angola's economy is driven by the oil sector, which accounts for more than $50 \%$ of GDP and $80 \%$ of government revenue. The nation's oil company, Sonangol, was established in 1976 to manage Angola's fuel production and distribution. The first commercial oil discovery in Angola was made in 1955 in the onshore Kwanza (Cuanze) basin. The industry has grown tremendously, despite the civil war which raged from 1975-2002. It should be noted however that currently, almost all the oil produced in Angola comes from offshore fields, off the coast of Cabinda, as well as deepwater fields in the lower Congo basin.

In 2013, oil production in Angola was estimated at 1.8 million barrels per day (bb1/d) of petroleum and other liquids, of which more than 1.7 million bbl/d was crude oil (EIA, 2014.5). Angola's oil production has risen by $15 \%$ from 2002 to 2008 , driven by production from multiple deepwater fields that were discovered in the 1990s. Figure 3 shows Angola's annual crude oil production and consumption from 2004 to 2013. It shows the nation's oil production peaked in 2008, with about 2 million bbl/d.

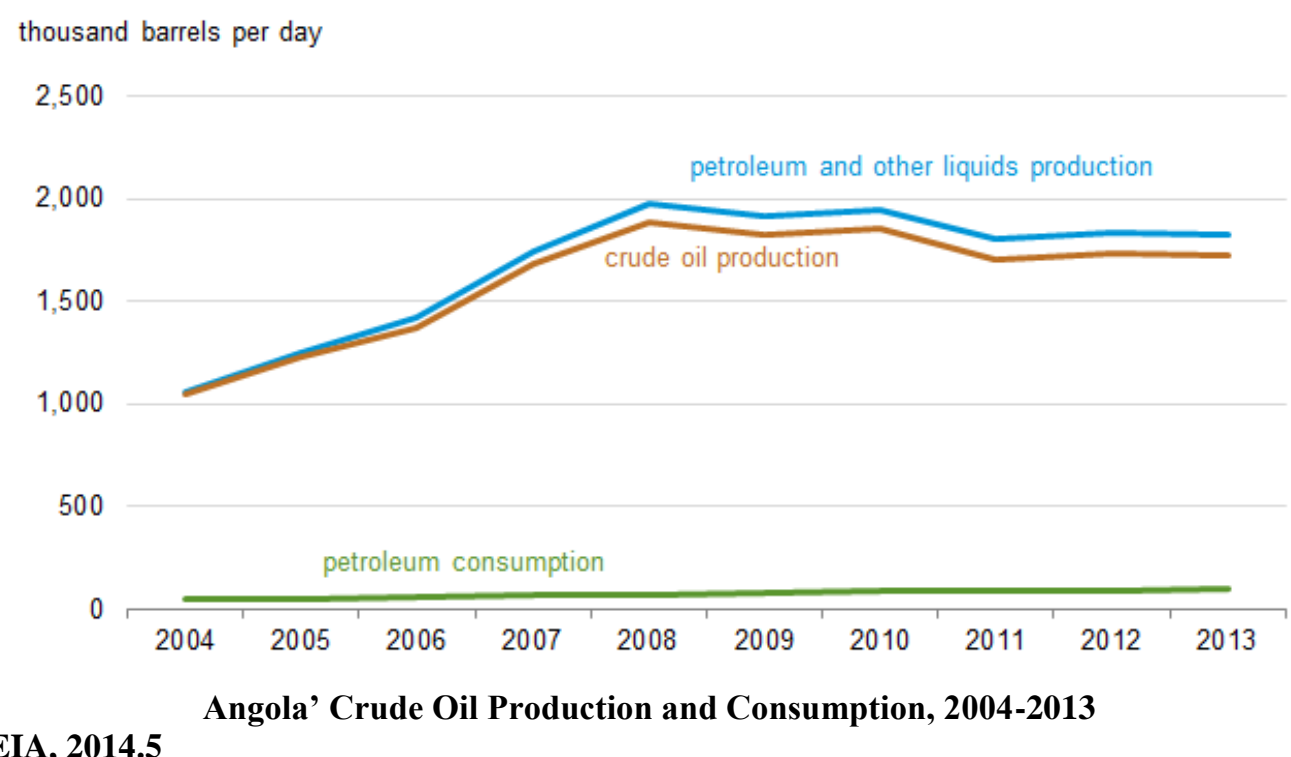

Source: EIA, 2014.5

Over the past few years, total oil production in Angola has averaged 1.8 million bbl/d, including $1.7 \mathrm{million} \mathrm{bbl} / \mathrm{d}$ of crude oil. Indeed, Angola's oil production profile has been stagnant as a result of persistent technical problems associated with water injection systems, gas cooling and floating, production, storage and offloading (FPSO) units with some projects (EIA, 2014.6).

Angola's economy has relied heavily on the oil sector, which accounts for over $95 \%$ of the nation's annual export revenue, making it the least-export diverse economy in Africa (World Bank, 2013.5). This development holds several implications for the nation's economy. First, oil exports generate foreign revenue inflows, causing the Kwanza, the domestic currency to appreciate and undermine the competitiveness of the non-oil sector. This development makes Angola's goods more expensive for foreign consumers, while foreign goods become cheaper for domestic consumers. Second, the oil sector and related industries tend to offer the highest returns to both financial and human capital, consequently attracting the lion's share of domestic credit, which employ the best educated and the most experienced labour in the economy. This further undermines the competitiveness of the non-oil industries. Finally, the revenue generated by oil boosts domestic demand for non-tradable sector. These developments create distortions that undermine the nation's economy.

\subsection{The Challenges of Inclusive Growth in Angola and Implications for the Social Sector}

Despite Angola's rich stock of natural resources, as well as accelerated economic growth in the last couple of decades, the nation still ranks $148^{\text {th }}$ out of 187 countries in the 2013 UNDP Human Development Index. In an affirmation to lack of inclusive growth in Angola's economy, unemployment has remained high, averaging an estimated 26\% since 2007 (AEO, 2012.19).

Poverty has also emerged as a development challenge in Angola. Near the end of the civil war in $2001 / 2002$, about $70 \%$ of the population was living on less than PPPUS $\$ 1.00$ per day, the international 
benchmark for the measurement of poverty in the developing world. In addition, the degree of income inequality was ranked amongst the highest in the world, with an estimated Gini coefficient of 0.62 (USAID, 2008.10). While the 2013 edition of the Integrated Household Survey and Population Well-Being Report affirms a reduction in the Head-count Poverty Ratio to $37 \%$ of the population, the poverty incidence is three times higher in the rural areas $(58 \%)$ than in urban centres $(19 \%)$. Also, only $30 \%$ of the poor-against $51 \%$ of the non-poor- have access to clean drinking water and there are similar data for sanitation $(40 \%$ and $72 \%$, respectively). Indeed, only $5 \%$ of the poor have access to all the three key infrastructure services, while for the non-poor the proportion rises to $32 \%$ (AEO, 2014.10).

\section{An Overview Of Nigeria's Economic Profile}

\subsection{Assessing Nigeria's Economic Performance: Recent Trends and Developments}

Nigeria's economic performance has fluctuated widely, particularly in the past three decades. The struggle with economic growth began in the late 1970s, when the nation's economy was hit by the effects of a global recession, resulting in negative growth. This was followed by economic stagnation in the 1980s and slow growth in the 1990s (United Nations, 2001.30). Indeed, over the period 1992 to 2002, Nigeria's annual GDP growth was measured at $2.25 \%$. Consequently, the nation's economy was ranked amongst the most volatile in the world for the period 1960 to 2000 (World Bank, 2003.5). However, with the re-emergence of democracy in the nation's polity in 1999, the new administration quickly began to implement a measure of economic reform agenda aimed at stimulating growth and embracing good governance, after a prolonged period of autocratic rule, characterized by a string military regimes. In response to the economic reform agenda, the nation's economy gathered momentum and was primed to take off by 2004 (Okonjo Iweala, 2007.2). In a development attributed to the results of economic reform, as well as favourable oil prices in the global market, Nigeria's economy has soared over the last decade, with an average annual GDP growth estimated at 8\%. This implies that the nation's economy is $170 \%$ larger today than it was a decade ago. Similarly, it also implies that the Nigerian non-oil economy has assumed an even larger dimension, 240\% higher than a decade ago (World Bank, 2013.7a).

In sharp contrast to the boom-bust cycles of previous decades, Nigeria has experienced no macroeconomic crisis in the past decade, in spite of the global economic crisis, which has undermined the world economy.

Nigeria, in an attempt to reflect the real measures of the nation's macroeconomic indicators, rebased its GDP from 1990 to 2010 (NBS, 2014.11; MGI, 2014.6). This development has resulted in an 89\% increase in the estimated size of the nation's economy. Consequently, Nigeria has now emerged as the largest economy in Africa, with an estimated nominal GDP of US\$510 billion, surpassing South Africa's US\$352 billion. The initiative also reveals a more diversified economy than previously thought. The development affirms that Nigeria maintained an impressive growth over a decade, estimated at 7.4\% growth of real GDP between 2003 and 2013. The performance was underpinned by favourable improvements in the non-oil sector, with real GDP growth of 5.4\%, 8.3\% and 5.4\% in 2011, 2012 and 2013, respectively. Agriculture, trade and services are the main drivers of non-oil sector growth. On the other hand, the oil sector, which had emerged as the cornerstone of the nation's economy in the past four decades, has slowed down in recent times, with unimpressive growth of $3.4 \%,-2.3 \%$ and $5.4 \%$ estimated for 2011, 2012 and 2013, respectively. However, economic output showed a robust growth in 2014, estimated at $6.3 \%$ The growth in the sector was undermined throughout 2013 by supply disruptions attributed to oil theft and pipeline vandalism, as well as weak investment in upstream activities with no new oil finds (AEO, 2014a) Table 3 shows Nigeria's recent macroeconomic indicators, including projections for 2015 and 2016.

Table 3: Nigeria - Selected Macroeconomic Indications, 2012-2016

\begin{tabular}{|l|l|l|l|l|}
\hline & 2013 & $2014(\mathrm{e})$ & $2015(\mathrm{p})$ & $2016(\mathrm{p})$ \\
\hline Real GDP growth & 5.4 & 6.3 & 5.0 & 6.0 \\
\hline Real GDP/capita Growth & 2.6 & 3.5 & 2.2 & 3.3 \\
\hline CPI Inflation & 8.6 & 8.1 & 8.3 & 7.6 \\
\hline Budget Balance \% GDP & 1.1 & 0.1 & -4.5 & -3.9 \\
\hline Current Account Balance\% GDP & 3.9 & 2.6 & -3.7 & -3.0 \\
\hline
\end{tabular}

Note: Estimates (e) and Projections (p)

Source: Africa Economic Outlook, 2015.3a

Table 3 also shows projections for real GDP growth of 5\% and 6\% for 2015 and 2016, respectively. However, the projections appear rather unrealistic, given the sharp decline in the global prices of crude oil since late 2014. 


\subsection{The Pivotal Role of Nigeria's Oil and Gas Sector to Contemporary Economic Growth}

Nigeria's economy is largely driven by the oil sector. Crude oil was discovered in Nigeria's Niger Delta region in 1956 and the nation began to export the commodity in 1958. The nation's economy actually began to depend on crude from since the early 1970s. Using 1970 as a benchmark, Nigeria gained an extra US $\$ 390$ billion in oil-related revenue over the period 1971-2005, or about 4.5 times 2005 GDP, expressed in constant 2000 US\$ dollars (Budina and Van Wijnbergen, 2008.2). This development has generated windfall revenues for the Nigerian government, with several implications. With rising oil revenue, policy makers in Nigeria marginalized the agricultural sector, which hitherto was the mainstay of the nation's economy.

However, the petroleum sector is an enclave economy, with little linkage to the other sectors of the economy. Also, it is susceptible to international price volatility, a factor that is driven by market demand. Therefore, over the past several decades, the pattern of revenue generated has featured few years of rising prices, followed by several years of falling prices, which creates fiscal imbalances and unleashes such macroeconomic shocks as unemployment, inflation, rising budget deficits and a debt 'overhang'. Furthermore, rising oil revenue in the past had unsettled the Nigerian economy, resulting in an increase in the value of the domestic currency or the Naira, rendering the nation's non-oil commodity prices uncompetitive in the international market, while making imported goods relatively inexpensive for domestic consumption. The petroleum sector has also been susceptible to corrupt practices, becoming a conduit for corrupt enrichment, particularly by technocrats and the elite. In recent times, renewed surges in crude oil prices have fueled Nigeria's economic growth, in recent times, as shown in figure 4.

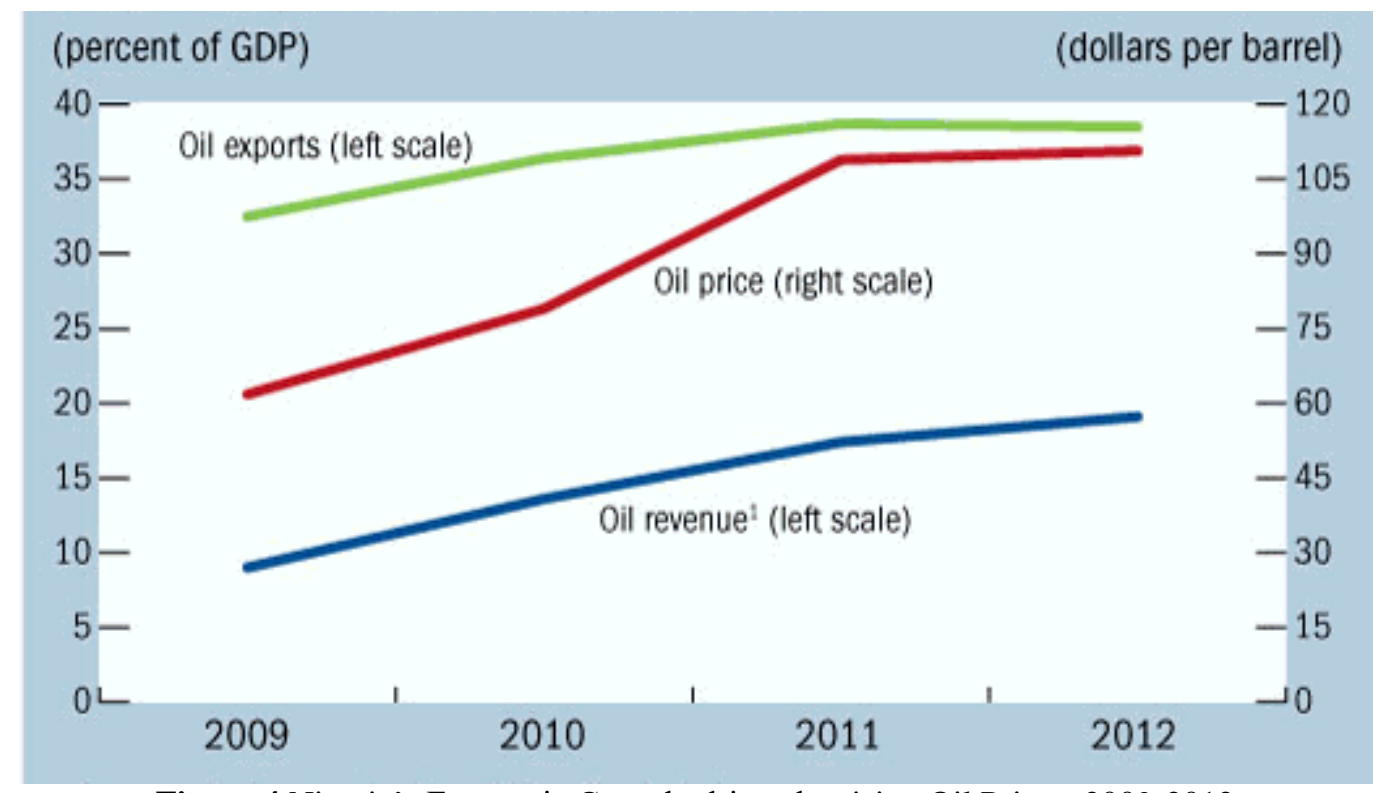

\section{Source: IMF Database}

Figure 4 Nigeria's Economic Growth, driven by rising Oil Prices, 2009-2012

The nation's contemporary economic growth profile, in the opinion of analysts, is largely driven by international crude oil prices (Hussain and Salinas, 2012.1). Nigeria is a major player in the global oil and gas industry. It is the largest crude oil producer and exporter in Africa. In 2012, it emerged as the world's fourth largest exporter of Liquefied Natural Gas (LNG). The oil sector accounts for $80 \%$ of annual government revenue, as well as $92 \%$ of its export proceeds. The nation's proven crude oil reserves are estimated at 37.2 billion barrels as of January, 2013, ranking the nation second largest in Africa, behind Libya (EIA, 2014a). Crude oil production peaked in Nigeria in 2005, at 2.44bbl/d. The industry experienced a decline thereafter, as violence linked to militant groups surged, forcing many industry players to shut production and abandon facilities. However, oil production recovered slightly in the aftermath of government's amnesty programme, which rehabilitated militants who agreed to discontinue attacks on oil installations in exchange for cash payments and training opportunities. Consequently, production began a steady rise since 2009, following a decline by more than $25 \%$ or an average of 1.8 million bbl/d. Figure 5 illustrates Nigeria's crude oil production and consumption from 2003 to 2012. It shows the peak in production in 2005 and the subsequent decline in the industry. 
thousand barrels per day

3,000

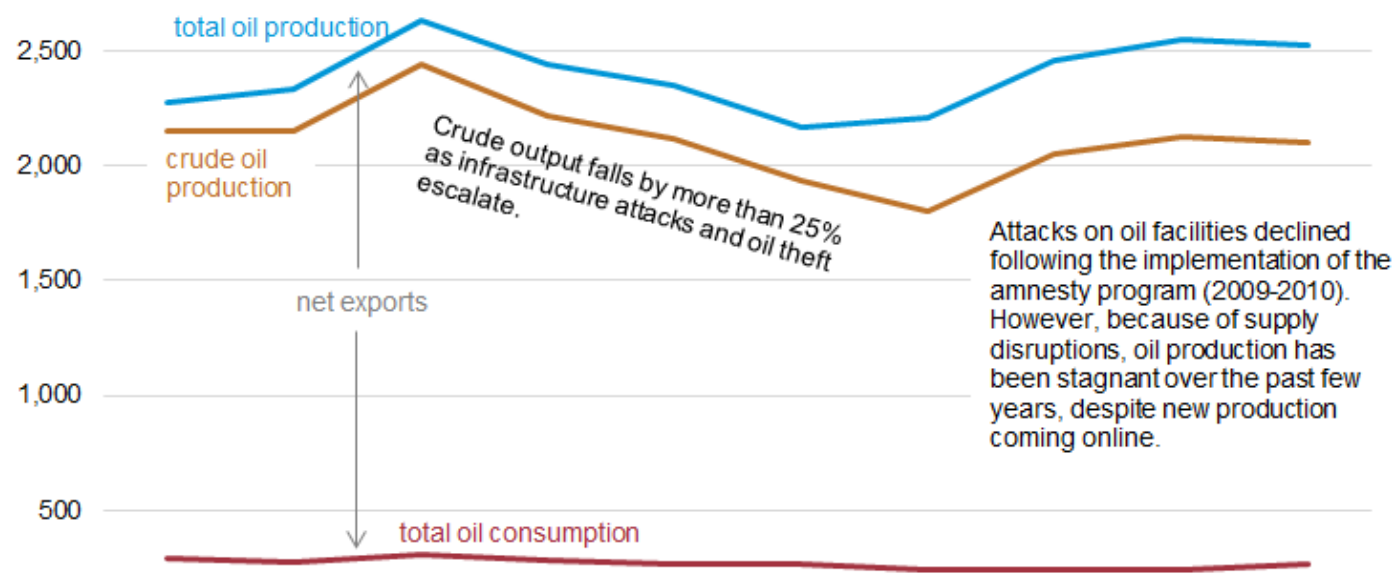

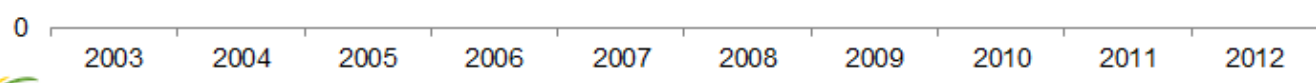

Source: EIA, 2014.6a.

Figure 5: Nigeria's Crude Oil Production and Consumption, 2003-2012

\subsection{The Challenges of Inclusive Growth in Nigeria and Implications for the Social Sector}

Nigeria's economic growth over the past decade is the highest in the nation's history. However, the positive economic performance is yet to trigger inclusive growth, as the benefits associated with economic growth have failed to trickle down to the poor. Consequently, poverty and unemployment remain as the major binding constraints to the nation's development aspirations (AEO, 2014.18a). The major challenge in Nigeria remains how to translate the nation's rich stock of natural resources into sustainable wealth for its teeming population. Despite the nation's recent growth profile, the fortunes of the poor are yet to be transformed. In a development paradox, the proportion of the people living in poverty had risen steadily from $65.5 \%$ in 1996 to $69.0 \%$ in 2010. Also, the Gini coefficient, a measure of inequality, also rose from 0.429 in 2004 to 0.047 in 2010. Indeed, available data show worsening poverty in the nation's rural areas, with a head count poverty ratio of $66 \%$ of the rural population in 2010 (AEO, 2012.5a).

In another affirmation to the lack of inclusive growth in Nigeria, the unemployment rates are sobering. According to National Bureau of Statistics (NBS), the 2011 Annual Socio-Economic Report reveals an unemployment rate of $24 \%$, compared to $21 \%$ in 2010 . The unemployment rates for the youth are even worse, at $38 \%$ for the population group aged 15-24. On the other hand, the unemployment rate for the population group aged $25-44$ years was placed at $22 \%$, while it was $18 \%$ for the $45-59$ years age group and $21 \%$ for those aged between 60 and 64 years. The unemployment rate was also higher in rural areas $(26 \%)$ than urban centres $(17 \%)$. The consequences of mass youth unemployment are evident in the rising number of cases associated with armed robbery, hostage-taking for ransom, illicit drug trafficking and addiction, militancy, including the 'Boko Haram' menace.

\subsection{Summary}

\section{Summary, Recommendations And Conclusion}

In recent times, inclusive growth has been acknowledged as a key ingredient in the transformation of people's lives, particularly in the developing world. The concept is described as the pattern and pace of economic growth that allows the poor to participate in, and benefit from, growth. While several economies in sub-Saharan Africa have experienced robust growth over the past couple of decades; the trend is largely unaccompanied by employment generation. It has therefore done little to reduce endemic poverty, which continues to undermine development efforts in the region. The lack of inclusive growth is a major feature of the economy in both Angola and Nigeria. Both countries rely on crude oil exports for government revenue and foreign exchange earnings. However, the oil sector is an enclave economy, with little linkages to the other sectors of the economy. It is also capital intensive, generating relatively few jobs, when compared to such other sectors as agriculture and services. The lack of inclusive growth poses a threat to social stability across subSaharan Africa, as policy makers struggle to mitigate the effects on the polity. 


\subsection{Recommendations}

This section presents recommendations aimed at fostering inclusive growth in sub-Saharan Africa. They include the following:

- Embrace Economic Reform: Several African countries have engaged in economic reform since the 1980s, with varying degrees of success. There is urgent need to fast track economic reform agenda, grounded in transparency and accountability. The aim of the reform agenda is to enhance the competitiveness of African economies and allow the private sector, acknowledged as the engine of economic growth, to general employment that is key to sustaining livelihoods and inclusive growth.

- Strengthen Institutions that Enhance Growth: A binding constraint to development in Sub-Saharan Africa is the prevalence of weak institutions. The establishment of key institutions is an imperative to promote inclusive growth. Such key institutions that enforce contract, promote law and order, as well as basic freedoms are necessary to inspire confidence in the economy and unleash the peoples' creative abilities.

- $\quad$ Promote Regional Integration: There is currently very little trade existing between African countries. Instead, most African countries engage with trade partners outside the region, in a development often blamed on the effect of colonialism. However, after more than fifty years since attaining political independence, African countries should first track regional integration aimed at boosting economic activity amongst African states. This is also the key to promoting regional integration, economic growth and development.

- Adopt Export Orientation: A key measure to foster inclusive growth is to gain entry into lucrative foreign markets for African commodities. While African countries should strive to retain traditional export markets in developed market economies, they should equally take advantage of opportunities unfolding in emerging economies. Lucrative export markets are now on the rise in China, India, and countries in developing Asia, as well as Latin America. African countries should take advantage of this trend and find markets for their commodities.

- Develop Social and Physical Infrastructure: Social and physical infrastructure in several African countries are in a state of disrepair. This development undermines economic activity and increases the cost of doing business. This is a key factor that renders many African economies uncompetitive. Therefore, concerted efforts should be made to rehabilitate infrastructure in the region and improve the delivery of such services as electricity, transportation, health care, education and communication.

- Deepen Poverty Reduction Strategies: In view of the endemic nature of poverty in Sub-Saharan Africa, policy makers in the region should integrate poverty reduction strategies into national development plans. This should embrace both short- and long-term anti-poverty measures aimed at rehabilitating the poor and creating wealth-enhancing opportunities for vulnerable elements in society, including youth, aged, women and the handicapped. Measures should also be taken to create social protection policies to mitigate impoverishment across African society.

\subsection{Conclusion}

Economic growth is critical to the transformation of African economies. However, economic growth should be inclusive in order to foster economic transformation. The high incidence of poverty in Sub-Saharan Africa remains a binding constraint to the realization of sustainable livelihoods critical to inclusive growth. Development experts within and outside the region have identified employment creation as a key mechanism for inclusive growth and have tasked policy makers in the region to create the enabling environment to boost employment. This is important to mitigating social instability in Sub-Saharan Africa. Inclusive growth is also a process that is critical to the competitiveness of African economies, which is a priority to policy makers in the region.

\section{References}

[1]. African Economic Outlook (AEO) (2015): Angola Country Profile. A Joint Publication by African Development Bank (AfDB); Organizanation for Economic Cooperation and Development (OECD); and United Nations Development Programme (UNDP).

[2]. - ------- (AEO) (2015a): Nigeria Country Profile.

[3]. -------(AEO) (2014): Global Value Chains \& Africa's Industrialization. A Joint Publication by African Development Bank (AfDB); Organizanation for Economic Cooperation and Development (OECD); and United Nations Development Programme (UNDP).

[4]. - --------- (AEO) (2012): Angola Country Profile.

[5]. - ------- (AEO) (2012a): Nigeria Country Profile.

[6]. African Development Bank (AfDB) (2012): Inclusive Growth Agenda. Briefing Note 6: Briefing Notes for AFDB's Long-term Strategy. Tunis.

[7]. Angola Brief (2012): Economic Growth in Angola to 2017: The Major Challenges. December. Vol. 2, No. 4. A Joint Publication by Chris Michelsen Institute (CMI) and Centro de Estudos e Investiga ç ã o Cientifica (CEIC).

[8]. Arieff, A., Weiss, M. and V. Jones (2010): The Global Economic Crisis: Impact on Sub-Saharan Africa and Global Policy Responses. CRS Report for Congress. Congressional Research Service, Washington, D.C.

[9]. Basu, A., Calamitsis, E. and D. Ghura (2000): Promoting Growth in Sub-Saharan African Learning that Works. International Monetary Fund. Washington, D.C. 
[10]. Budina N. and S.Van Wijnbergen (2008): Managing Oil Revenue Volatility in Nigeria: The Role of Fiscal Policy

[11]. Corso, E. (2011): Inclusive Growth Analysis and HRV: A Methodological note. The World Bank. Washington, D.C.

[12]. Energy Information Administration (EIA) (2014): Angola Country Brief. United States Department of Energy. Washington, D.C.

[13]. - ---- (EIA) (2014a): Nigeria Country Brief.

[14]. Hussain, M, and G. Salinas (2012): High Oil Prices, Reform Agenda Improve Nigeria's Prospects. African Department. International Monetary Fund (IMF). Washington, D.C.

[15]. IanChovichina, E. and S.Lundstrom (2009): Inclusive Growth Analytics: Framework and Application. World Bank. Washington, D.C.

[16]. International Labour Organisation (ILO) (2014): Global Employment Trends 2014. Risks of a Jobless Recovery? Geneva.

[17]. International Monetary Fund (IMF): World Economic Outlook. Slowing Growth, Rising Risks. September. Washington, D.C

[18]. Kakwani, N. and E. Pernia (2000): 'What is Pro-Poor Growth?' Asia Development Review: Studies of Asian and Pacific Economic Issues, Vol. 18, No. 1, Mandaluyong City, Asia Development Bank

[19]. KPMG (2013): Angola: Country Profile. KPMG Africa Region 2012/2013. www.pkmgafrica.com

[20]. Mckinsey Global Institute (MGI) (2014): Nigeria's Renewal: Delivering Inclusive Growth in Africa's Largest Economy. July.

[21]. National Bureau of Statistics (NBS) (2014): Rebasing National Accounts Statistics. Methodology Notes on Gross Domestic Product (GDP) Rebating Exercise.

[22].

[23]. Okonjo-Iweala, N. (2007): Nigeria's Economic Reforms: Progress and Challenges. Brookings Global Economy and Development. Working Paper No. 6. Washington, D.C.

[24]. Ramos, A., Ranieri, R., and J. Lammens (2013): Mapping Inclusive Growth in Developing Countries'. IPC - IG Working Paper, No 105, Brasilia, International Policy Centre for Inclusive growth.

[25]. Sala-i-matin, X. and M. Pinkovskiy (2010): African Poverty is Falling....Much Faster Than You Think. National Bureau of Economic Research (NBER) Working Paper, 15775. Cambridge.

[26]. Sy, A. (2014): Jobless Growth in Sub-Saharan Africa. Global Economy and Development. Africa Growth Initiative. Brookings Institution. Washington, D.C.

[27]. The Economist (2010): Sub-Saharan Africa's GDP from the Print Edition. October 28. London.

[28]. United Nations (2001): Nigeria Common Country Assessment. A Report Compiled by the United Nations Agencies in Nigeria. Lagos.

[29]. United Nations Economic Commission for Africa (UNECA) (2011): Promoting High-Level Sustainable Growth to Reduce Unemployment in Africa. ECA Policy Brief No. 002.

[30]. United Nations Development Programme (UNDP) (2000): Overcoming Human Poverty. New York.

[31]. United States Agency for International Development (USAID) (2008): Angola: Economic Performance Assessment Washington, D.C.

[32]. World Bank (2014): Global Economic Prospects. Sub-Saharan Africa, June. Washington, D.C.

[33]. -------- (2014a): African's Pulse An Analysis of Issues Shaping Africa's Economic Future. April. Vol. 9. Washington, D.C.

[34]. -------- (2013): Angola Economic Update. Economic Developments and Issues shaping Angola's future. June. Issue 1.

[35]. - ------- (2013a): Nigeria Economic Report No. 1 May. Washington, D.C.

[36]. --------- (2011): Africa's Pulse, An Analysis of Issues Shaping Africa's Economic Future. April. Vol. 3. Washington, D.C.

[37]. -------- (2009): What is Inclusive Growth? A Note prepared by Ianchovichina, E. and S. Lundstrum, with input from Garrido, L. $10^{\text {th }}$ February. Washington, D.C.

[38]. ------- (2003): Nigeria Policy Options for Growth and Stability. Report No. 26215-NGA. Washington, D.C.

[39]. --------- (2000): Attacking Poverty: Opportunity, Empowerment and Security. World Development Report, $2000 / 2001$. Washington, D.C.

[40]. World Report International (WRI) (2011): Angola: El Dorado of Africa. London. www.worldreport-ind.com.

S. Igbatayo. "The Challenges of Inclusive Growth in Sub-Saharan Africa: A Comparative Analysis of Angola and Nigeria." IOSR Journal of Economics and Finance (IOSR-JEF) 8.4 (2017): 72-82. 